\title{
Population dynamics of the non-native crab Petrolisthes armatus invading the South Atlantic Bight at densities of thousands $\mathbf{m}^{-2}$
}

\author{
A. L. Hollebone, M. E. Hay* \\ School of Biology, Georgia Institute of Technology, 311 Ferst Drive, Atlanta, Georgia 30332-0230, USA
}

\begin{abstract}
The green porcelain crab Petrolisthes armatus recently invaded oyster reefs of the South Atlantic Bight. In 2 estuaries of coastal Georgia, USA, crab densities reached peak densities of 4000 to $11000 \mathrm{crabs} \mathrm{m}^{-2}$ in some periods and locations. Densities generally were higher in the low versus the high intertidal and in the lower versus upper regions of the estuaries. In warmer months, 20 to $90 \%$ of adult females were gravid, recruits were dense, and population levels were high. In colder months, densities dropped by 64 to $>99 \%$. Male:female ratios were near 1:1 across times and locations. Maximum mean densities of $P$. armatus in Georgia were 37 times the highest densities recorded in the presumptive native range. Crabs in the new range reproduced at a smaller size, and the percentage of gravid females was similar between the old and new range. Thus, population fecundity in Georgia exceeds that of the native range by more than 1 order of magnitude. Densities of native mud crabs in the genera Panopeus and Eurypanopeus were unrelated to, or positively correlated with, densities of the exotic crabs; correlations were never significantly negative. The impact of Petrolisthes armatus on native communities is unclear, but could be considerable if this filter-feeding crab impacts oysters, which are the foundation species of inshore reefs.
\end{abstract}

KEY WORDS: Marine invasion · Invasive species · Exotic species · Crab densities · Population dynamics $\cdot$ Species boundaries

\section{INTRODUCTION}

Biological invasions threaten natural communities and alter ecosystem structure (Mooney \& Drake 1986, Simberloff et al. 1997), so studies of the traits and impacts of exotic species can provide insights into processes affecting community assembly and global change as well as provide management options regarding invasive species (Lodge 1993). Most studies of invasions have focused on terrestrial or freshwater habitats where invaders have strongly impacted native species; studies of marine invasions are less common despite several being well-known and having substantial ecological consequences (Carlton \& Geller 1993, Cohen \& Carlton 1998, Ruiz et al. 1999).

Oyster reefs are the major hard-substrate communities in coastal areas of the South Atlantic Bight, USA, and oysters serve as ecosystem engineers that produce the biogenic structure upon which many native species depend (Lenihan \& Peterson 1998). These reefs have rarely been affected by invasive macrofauna known to be succeeding in ports and estuaries within other regions of the United States (Ruiz et al. 1997, 1999, Cohen \& Carlton 1998). However, sometime in the early 1990s, the green porcelain crab Petrolisthes armatus colonized oyster reefs in South Carolina, rapidly increasing from single individuals $\mathrm{m}^{-2}$ in 1995 to over $16000 \mathrm{~m}^{-2}$ by August 1999 (South Carolina Department of Natural Resources). The native range of this crab presumably includes the eastern Pacific (Gulf of California to Peru), the western Atlantic (Bermuda, Gulf of Mexico, Caribbean, and Brazil), and western Africa, where the greatest known densities of the crab reach only $\leq 305$ individuals $\mathrm{m}^{-2}$ (Oliveira \& Masunari 
1995). Coen \& Heck (1983) listed the crab as occurring in Georgia a decade prior to its discovery in South Carolina, but the basis for this listing is unclear (K. Heck pers. comm.). No other reports of P. armatus in Georgia occurred during the 1980s.

In its new range, Petrolisthes armatus is found primarily in oyster reef habitats of Georgia and South Carolina. Although this crab has been found across a wide area of the tropical Atlantic and Pacific on rocky shores (Oliveira \& Masunari 1995), sand reefs built by sabellid worms (Micheletti-Flores \& Negreiros-Fransozo 1999), and even mangrove prop roots (Sheridan 1992), very little is known about the crab's distribution, habitat preference, seasonal fluctuations, population structure, and food web or community-level effects (but see Sheridan [1992] for density fluctuations in Rookery Bay, Florida, and Oliveira \& Masunari [1995] and Micheletti-Flores \& Negreiros-Fransozo [1999] for population dynamics in southern Brazil). To provide an initial assessment of the invasion in coastal Georgia, we asked the following questions: (1) What are the spatial and temporal patterns of $P$. armatus densities in tidal creeks of its new range, (2) What are the demographic patterns of the crab (including sex ratios) across seasons, regions, and tidal heights, (3) What are the reproductive patterns of the crab, (4) What are the distributional patterns of cooccurring native crabs, and (5) How do native crab distributions correlate with those of the non-native crab?

\section{MATERIALS AND METHODS}

Study sites. Petrolisthes armatus and associated oyster reef crabs were monitored within 2 Georgia estuaries separated by about $75 \mathrm{~km}$ (Fig. 1). The southern estuary at Sapelo Island (part of NOAA's National Estuarine Research Reserve System) includes the Duplin River ( 12.5 km in length). The Duplin River does not have a significant freshwater source, and is better described as an elongated tidal embayment (Ragotzkie \& Bryson 1955, Chalmers 1997). The transport of materials in the river is primarily diffusive except when there is heavy rainfall at low tide which can nearly replace the water in the upper regions of the river (Chalmers 1997). The Duplin River has 3 tidal prisms along its length (Ragotzkie \& Bryson 1955). Strong tidal currents at the mouth of the river and the lack of fresh- water input at the head of the river maintain a wellmixed, vertically homogeneous water column within each defined tidal prism, but the overall impact is little advective transport of water and materials (Ragotzkie \& Bryson 1955, Bahr \& Lanier 1981). Thus, waters of the upper and lower regions are hydrologically isolated from one another (Chalmers 1997).

The northern estuary encompasses the rivers, creeks, and marshes near Skidaway Island (Fig. 1). This is a riverine estuary that is influenced by saline waters at its mouth and freshwater in its upper regions. Such estuaries can show a well-defined vertical salinity stratification where freshwater overrides the higher density salt water, thus forming salt-wedges (Bahr \& Lanier 1981). When tidal flow is strong enough to prevent the freshwater source from dominating circulation patterns, a partially mixed estuary with moderate salinity stratification can occur (e.g. Altamaha and Ossabaw Sounds, Georgia) (Bahr \& Lanier 1981). The study area included the mouth of the Wilmington River (where it meets Wassaw Sound) up to its intersection with the Skidaway River $(\sim 7 \mathrm{~km})$ and into a large tidal

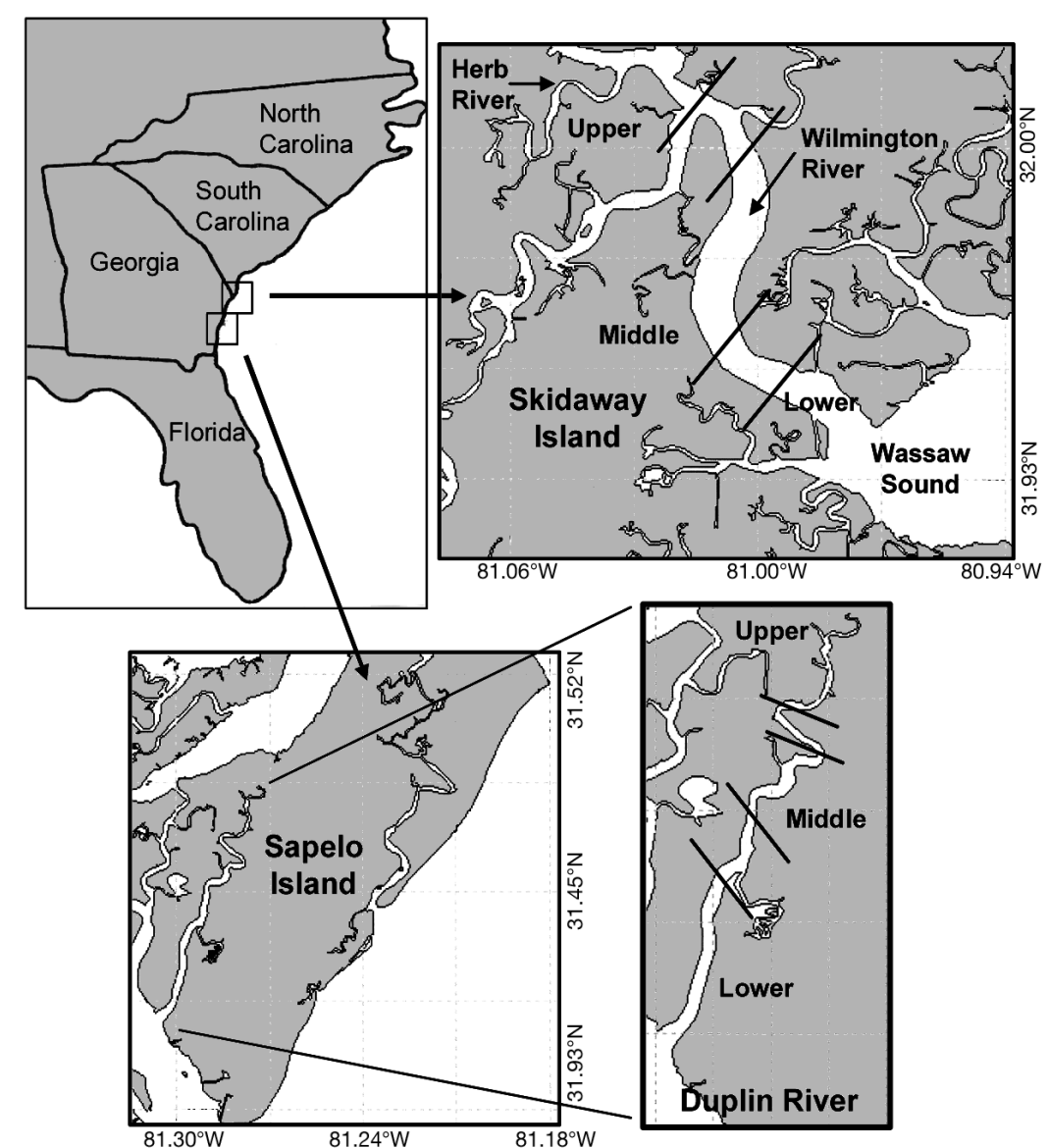

Fig. 1. Skidaway Island and Sapelo Island, Georgia, USA, showing locations of the monitoring regions (Upper, Middle, and Lower) in each estuary 
creek (Herb River). There are no known tidal prisms in this region, but frequent gyres of circulating water occur continuously along the river's length (C. Li pers. comm.).

Both estuaries are dominated by marsh cordgrass (Spartina alterniflora) in the upper tidal heights, oyster reefs (Crassostrea virginica) and associated biota in the middle tidal heights, and muddy sediments in the lower intertidal. The estuaries are subject to semidiurnal tides with a tidal range of 2 to $4 \mathrm{~m}$ (Bahr \& Lanier 1981). Thus, depending upon the height of the tide, portions of the middle and/or lower intertidal are exposed on most days.

Despite the hydrodynamic differences between the 2 estuaries, both appear to have stronger and more frequent physical disturbances in the lower versus upper regions due to wind-wave and tidally generated currents. The middle regions are influenced by both marine and riverine processes, thus these regions are generally more turbid throughout the tides. The upper regions incorporate the network of tidal creeks that drain the surrounding salt marshes and are generally characterized as low-energy, sedimentary environments (Bahr \& Lanier 1981).

Monitoring. We monitored crab density, size, and sex along estuarine gradients in the 2 locations as a function of season and tidal height throughout the year (August 2003 to July 2004). The rivers of both estuaries were divided into 3 regions: (1) Upper, (2) Middle, and (3) Lower, with unmonitored sections separating each region (Fig. 1). Within each region we marked 20 oyster reef monitoring plots with PVC poles and took GPS coordinates of each location. Monitoring plots were typically separated from each other by $\geq 20 \mathrm{~m}_{\text {; how- }}$ ever, in the Upper region of the Duplin River where reefs became sparse our plots were separated by $\sim 10 \mathrm{~m}$.

We initiated monitoring in early June 2003 (Wilmington River: June 2 to 7, Duplin River: June 9 to 12). At each of the 20 plots within each region, we placed a $22 \times 15 \mathrm{~cm}\left(\sim 0.03 \mathrm{~m}^{2}\right)$ plastic basket at a high (top edge of the oyster reef, $\sim 1$ to $2 \mathrm{~m}$ above mean lower low tide) and low (just above where oysters end and mud begins, $\sim 0$ to $0.5 \mathrm{~m}$ above mean lower low tide) tidal height of the oyster reef along the same vertical transect and with similar basket orientation to the waterline (see inset in Fig. 2). Baskets were nestled into the oyster reef and anchored using rebar stakes. Baskets had perforated sides (nine $5.4 \mathrm{~cm}$ long and $1.4 \mathrm{~cm}$ tall halfmoon-shaped holes along the length and 2 along the width) and open tops, allowing movement of crabs into and out of the baskets. Each basket was initially hand-packed to its top with site-specific oyster reef substrate (immediately adjacent to each basket), including any reef-associated organisms in that vol- ume. Crevice size, shape, and number of oysters in each basket appeared visually similar to that of the natural reef.

We monitored crabs in these baskets on a quarterly basis during low tides ( 2 to $3 \mathrm{~h}$ before and after the low tide) [Wilmington River: (1) August 25-September 3, 2003, (2) December 2-18, 2003, (3) April 1-15, 2004, (4) July 7-12, 2004; Duplin River: (1) September 5-8, 2003, (2) November 20-22, 2003, (3) March 16-18, 2004, (4) June 30-July 2, 2004]. For the initial sampling, 10 of the 20 plots in each region for each estuary were randomly chosen and sampled. The second set of 10 plots was sampled during the following sampling period. The plots sampled were alternated in this manner throughout the monitoring. In cases where baskets or all material within the baskets were lost due to physical disturbances (this happened for 5 baskets out of a total of 240 possible baskets for the Duplin River and for 30 out of a total of 240 possible baskets for the Wilmington River, mostly in the lower region during winter storms), the closest alternate basket was sampled. All baskets that were lost or empty were replaced and filled to the top for future sampling. Thus, after the initial sampling, most individual baskets were monitored at 6 mo intervals, with a few (2 to 9 baskets) from each time-point used after 3 mo. In preliminary experiments, baskets achieved a stable density of Petrolisthes armatus in 1 mo (A. L. Hollebone unpubl. data). Thus, the 3 to 6 mo between monitoring considerably exceeded the time required for recovery following disturbance due to previous sampling.

To monitor crab densities, baskets were removed from their anchors and materials within each basket transferred to a closed container. All material was retrieved and the volume noted for those baskets that were $\leq 2 / 3$ full of oyster habitat (due to physical disturbance). If the baskets were 75 to $100 \%$ full, the volume was noted and half of the material was taken. The volume was split by overturning the basket over 2 plastic containers (the width of two of these containers approximated the length of one monitoring basket). The content of one container was taken and the content of the other was returned to the monitoring basket. All baskets were resecured in their original positions and filled to $100 \%$ with surrounding oyster substrate.

Upon return to the laboratory, all crabs (both native and non-native) were removed, counted, sized (carapace width $=\mathrm{CW}$ ), sexed (see Oliveira \& Masunari 1995), and preserved in $70 \%$ ethanol or $10 \%$ formalin. If there were $<40$ crabs in a sample, all were sized and sexed. Samples containing $>40$ crabs were subsampled. This involved (1) pouring crabs into a sorting tray that had been divided into 12 equal sections, (2) separating crabs from one another, (3) slightly suspending 
the crabs with a few milliliters of water, and (4) selecting, sexing, and measuring the first 30 crabs encountered in randomly selected sections of the tray (sections were chosen using a random numbers table, and the entire carapace had to be within the section chosen to be counted). Additional sections were sampled until 30 or more crabs had been assessed.

Data analyses. We determined the estuarine-wide density patterns of exotic porcelain crabs and native mud crabs (Panopeus herbstii and Eurypanopeus depressus combined) scaled to $1 \mathrm{~m}^{2}$ along the lengths of the 2 rivers, as a function of tidal height and time period. Because a sampling basket covered $3.3 \%$ of a $1 \mathrm{~m}^{2}$ area, we multiplied each value by 30.3 to scale densities to $1 \mathrm{~m}^{-2}$ ) We included mud crabs because these were the most common native crabs co-occurring with the invasive crabs within the oyster reefs. Data sets were tested for normality (Ryan-Joiner W, p > 0.050 ) and equality of variances (Bartlett's test, p > 0.050, Zar 1999). Because of non-normality, the data for $P$. armatus were log-transformed and data for the native mud crabs were square root transformed. These transformations improved the homogeneity of variances for all the monitoring data, but in some cases (e.g. low sample size in the lower region of the Wilmington River in December 2003) equality of variances for the entire data set was not achieved. Following transformation we performed 3-way ANOVAs for porcelain crabs and for mud crabs, with estuary, time period, and tidal height as fixed factors and region of the river nested within estuary.

We evaluated how size classes of Petrolisthes armatus (males and females combined) were distributed across regions, tidal heights, and time by plotting mean $\left( \pm \mathrm{SE}\right.$ ) density scaled to crabs $\mathrm{m}^{-2}$ (from newly settled megalopae through the largest adults, with size measured as carapace width in $\mathrm{mm}$ ). We determined mean size for each time-region combination.

Size classes and mean $( \pm \mathrm{SE})$ densities were determined for male and female Petrolisthes armatus basket $^{-1}$ (scaled as above) across all regional, tidal height, and time period combinations. The sex ratio of $P$. armatus for each region $\times$ tidal height plot (these calculations ignored megalopae that could not be reliably sexed) was calculated from the total pooled sample of all males and all females in that region, tidal height, and season. We did not calculate a ratio for each basket because during some samplings several baskets contained no crabs, or only one or a few of the same sexsuch low densities produce large variances in ratios that may not be representative of samples for larger numbers of individuals. We assessed whether the frequency of males within each region and season were significantly different from an expected frequency of $50 \%$ by the $\chi^{2}$ test.
We assessed all females $\geq 3 \mathrm{~mm} C W$ (the smallest size at which we noted ovigerous females) to determine the proportion of ovigerous females across sites and seasons. Data were arcsine transformed, tested for normality and equality of variances, and then analyzed using a 2-way ANOVA with fixed factors of region and tidal height. Time was not included as a fixed factor because gravid females were not present during each monitoring period. To determine the potential population-level fecundity of crabs in the invaded range versus the presumptive native range, we determined the proportion of mature females that were gravid across all locations and seasons in both estuaries and compared this proportion with the overall proportion derived from Oliveira \& Masunari's (1995) data for populations in Brazil.

To assess how this invasive crab might be interacting with native crabs in oyster reef habitats, we correlated the densities of native mud crabs (dominated by 2 species, Panopeus herbstii and Eurypanopeus depressus) against densities of Petrolisthes armatus using Fisher's $r$ to $z$ to determine the relation of these crabs among regions, between tidal heights, and over time.

\section{RESULTS}

\section{Overall densities}

Densities of Petrolisthes armatus in the Duplin River estuary ranged from $\sim 15$ to $3900 \mathrm{crabs} \mathrm{m}^{-2}$ during warmer months but dropped to maximal mean densities of only $400 \mathrm{crabs} \mathrm{m}^{-2}$ after colder portions of the year (March; Fig. 2A). Between the end of the warmest period (November) and the end of the coldest period (March), densities decreased by $\sim 64$ to $69 \%$ in the Upper region, $\sim 85$ to $93 \%$ in the Middle region, and $\sim 91$ to $95 \%$ in the Lower region of the estuary. P. armatus densities in the Wilmington River estuary ranged between $\sim 790$ and $11200 \mathrm{crabs} \mathrm{m}^{-2}$ during warmer months, but during colder months (reflected in the April 2004 data; Fig. 2B), densities decreased by 89 to $>99 \%$ (averaging only $\sim 20$ to 165 crabs $\mathrm{m}^{-2}$ across all regions compared to the December 2003 densities). The 3-way ANOVA indicated that estuary, time period, and tidal height, as well as the nested factor of region in estuary, all significantly affected $P$. armatus density ( $\mathrm{p} \leq 0.015$, Table 1$)$. There were significant time $\times$ estuary, time $\times$ region nested in the estuary, and tidal height $\times$ estuary interactions $(p \leq 0.020)$. The time $\times$ tidal height interaction was nearly significant $(p=0.068)$, but other higher order interactions were not significant $(\mathrm{p} \geq$ 0.215 , Table 1). 

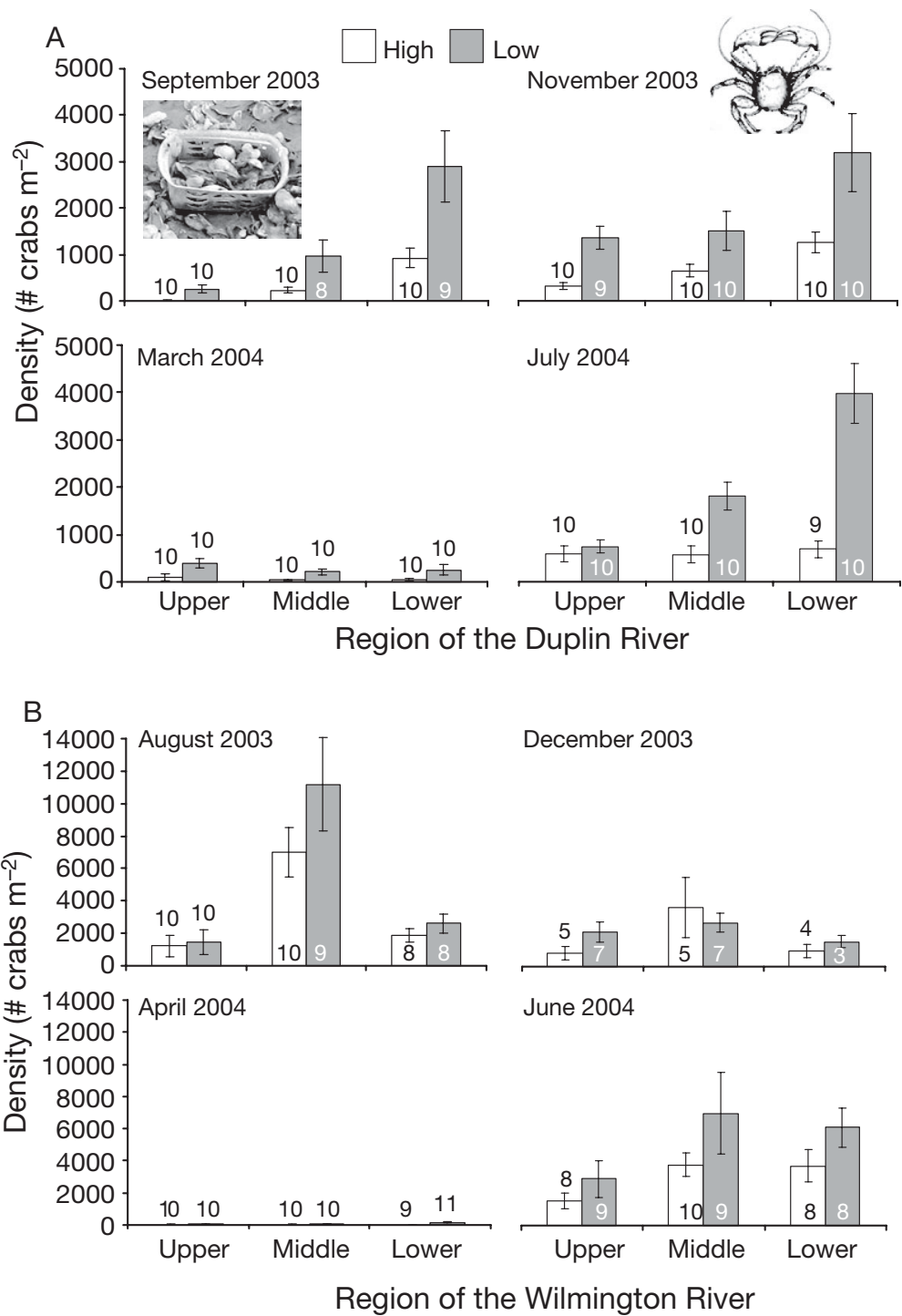

Fig. 2. Petrolisthes armatus. Densities (mean $\pm \mathrm{SE}$, scaled to $1 \mathrm{~m}^{2}$ ) in (A) Duplin River and (B) Wilmington River across regions, tidal heights (high and low intertidal), and sampling periods. Numbers within or above bars indicate number of replicate baskets sampled. For statistical analyses see Table 1. Inset in (A) shows an oyster basket
Sex ratios rarely differed significantly from an expected ratio of 1:1 regardless of estuary, time, region, or tidal height, (Table $2, \chi^{2}$ test, $\mathrm{p}>0.050$ ). This analysis entailed 48 separate statistical tests. One could expect 2 to 3 significant differences with $\mathrm{p}=0.050$ by chance alone (i.e. $48 \times 0.05=2.4$ significant differences expected), so we do not interpret the 3 differences we detected as meaningful.

A large proportion of mature females ( $\geq 3 \mathrm{~mm} \mathrm{CW}$ ) were gravid in the warm months of the year (Duplin River: 40 to $85 \%$ in September and 20 to $70 \%$ in July, Wilmington River: $\sim 70$ to $90 \%$ in August and $\sim 25$ to $75 \%$ in June). Females were rarely gravid during the colder months (Duplin River: $\sim 0$ to $10 \%$ in November and March, Wilmington River: $\sim 0$ to $15 \%$ in December and April) (Fig. 5). The proportion of mature females that were gravid across all locations and times was $30.5 \%$ in the Duplin River and $48.1 \%$ in the Wilmington River.

In the Duplin River, a larger proportion of mature females were gravid in the low versus the high tidal habitats during all sampling periods when gravid females were present $(p \leq 0.012$ for November and July, and nearly significant with $\mathrm{p}=0.065$ in September). Region had a significant effect in July $(p=0.025)$ when a larger proportion of females were gravid in the Upper versus Middle or Lower region of the estuary (Fig. 5A). In the Wilmington River estuary, tidal height never significantly affected the percentage of females that were gravid. In June, more females in the upper estuary tended to be gravid ( $\mathrm{p}=0.039$ for region; Fig. 5B). There was never a significant region $\times$ tidal height interaction for either estuary.

\section{Demographics}

Recruitment (appearance of crabs $<3 \mathrm{~mm} \mathrm{CW}$ ) in both estuaries occurred primarily during the warmer months of June to September (Figs. 3 \& 4). Recruits (megalopae), juvenile crabs, and gravid females (Figs. 3 to 5) were absent, or nearly so, following the coldest months of the year (March and April). Some crabs of reproductive size $(\geq 3 \mathrm{~mm} \mathrm{CW})$ persisted through the winter months. Although crabs were generally more abundant in the low versus high intertidal, size class distributions were roughly similar for the 2 tidal heights with the exception that the largest size classes tended to occur in the low tidal zone.

\section{Biological factors}

The 2 most common mud crabs, Panopeus herbstii and Eurypanopeus depressus, were abundant in both the low and high tidal areas and varied less than Petrolisthes armatus as a function of time period or location within the estuary (Fig. 6). Throughout the year, mud crab densities were $\sim 580$ to $1610 \mathrm{crabs} \mathrm{m}^{-2}$ in the Duplin River and 340 to 1530 crabs m$^{-2}$ in the Wilmington River. While P. armatus were 10 to 100 times more common in warmer months than in the early spring, mud crabs were only 1 to 3 times more common in warm periods. As with porcelain crab densities, mud crab densities exhibited significant effects 
Table 1. Petrolisthes armatus. 3-way ANOVA of density with estuary, time period, and tidal height as fixed factors and region nested within estuary

\begin{tabular}{|c|c|c|c|c|c|c|}
\hline Source & $\mathrm{df}$ & Seq SS & Adj SS & Adj MS & $F$ & $\mathrm{p}$ \\
\hline Estuary & 1 & 3.6338 & 3.8152 & 3.8152 & 5.97 & 0.015 \\
\hline Time period & 3 & 266.5887 & 268.9672 & 89.6557 & 140.24 & $\leq 0.001$ \\
\hline Tidal height & 1 & 36.1261 & 32.8580 & 32.8580 & 51.40 & $\leq 0.001$ \\
\hline Region (Estuary) & 4 & 46.1801 & 42.1820 & 10.5455 & 16.50 & $\leq 0.001$ \\
\hline Estuary $\times$ Time & 3 & 30.3143 & 30.5927 & 10.1976 & 15.95 & $\leq 0.001$ \\
\hline Estuary $\times$ Tidal height & & 4.1075 & 3.4697 & 3.4697 & 5.43 & 0.020 \\
\hline Time period $\times$ Tidal height & 3 & 4.3730 & 4.5976 & 1.5325 & 2.40 & 0.068 \\
\hline Time period $\times$ Region (Estuary) & 12 & 42.6752 & 42.1898 & 3.5158 & 5.50 & $\leq 0.001$ \\
\hline Tidal height $\times$ Region (Estuary) & 4 & 3.2927 & 3.3043 & 0.8261 & 1.29 & 0.272 \\
\hline Estuary $\times$ Time period $\times$ Tidal height & 3 & 1.0211 & 0.8654 & 0.2885 & 0.45 & 0.717 \\
\hline Time period $\times$ Tidal height $\times$ Region (Estuary) & 12 & 9.9775 & 9.9775 & 0.8315 & 1.30 & 0.215 \\
\hline Error & 386 & 246.7701 & 246.7701 & 0.6393 & & \\
\hline Total & 433 & 695.0600 & & & & \\
\hline
\end{tabular}

of the 3 fixed factors in the model (estuary, time period, and tidal height) as well as region nested within estuary ( $\mathrm{p} \leq 0.029$, Table 3 ). The time $\times$ estuary and time $\times$ region in the estuary interactions had significant effects on mud crab densities $(p<0.001)$, but time $\times$ tidal height, tidal height $\times$ estuary, and tidal height $\times$ region in the estuary did not $(p \geq 0.267)$. The interaction of all 3 fixed factors was not significant $(p=0.445)$, but nesting region into the estuary factor did significantly affect densities ( $p=0.049$, Table 3 ).

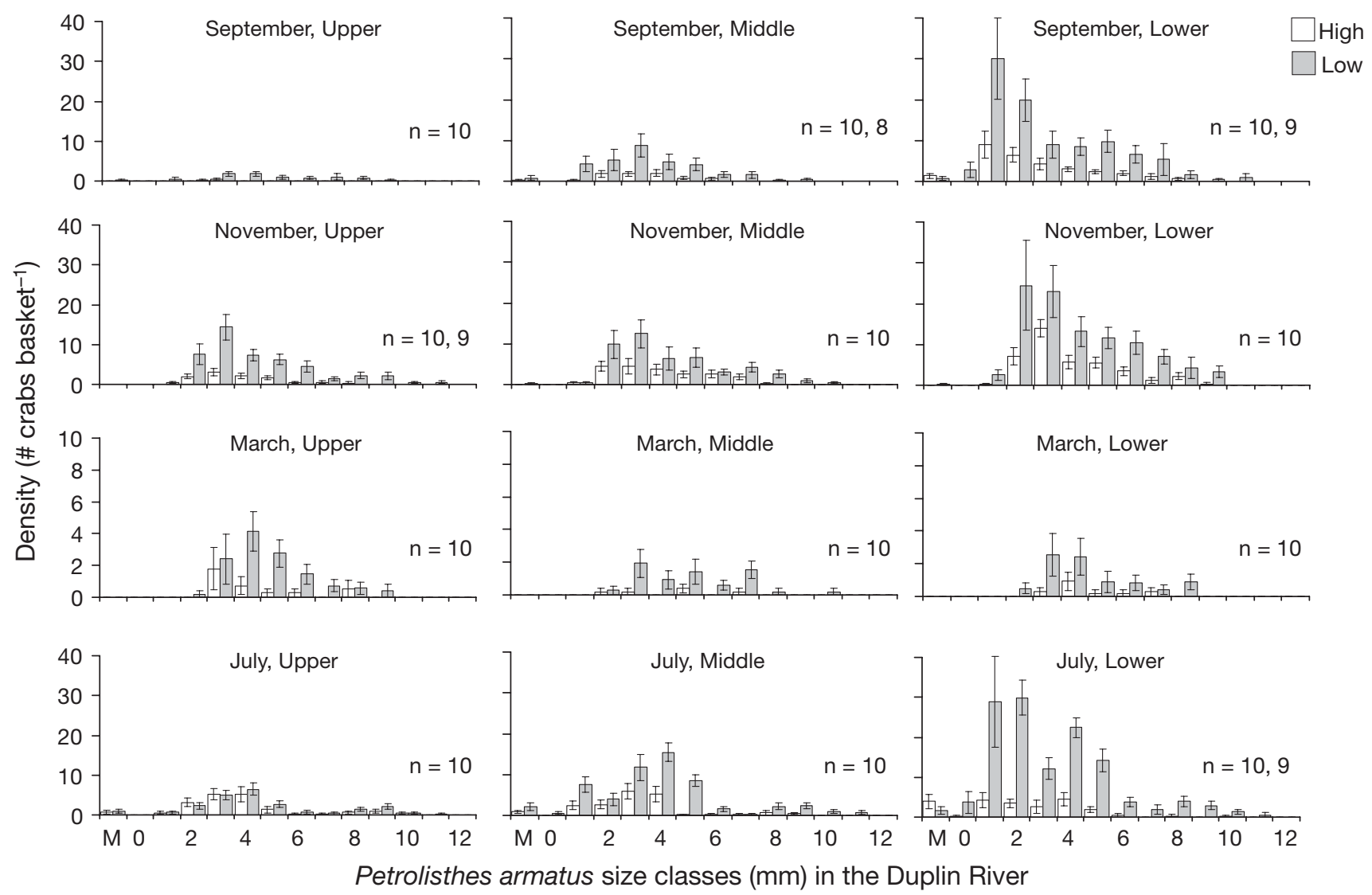

Fig. 3. Petrolisthes armatus. Densities (mean $\pm \mathrm{SE} \mathrm{m}^{-2}$ ) by size class in the Duplin River across regions, tidal heights (high and low intertidal) and sampling periods. $M=$ megalopae (newly settled crabs); $0=0-0.9 \mathrm{~mm} \mathrm{CW} ; 2=2-2.9 \mathrm{~mm} C W$; etc. Note different $y$-axis scale for March 


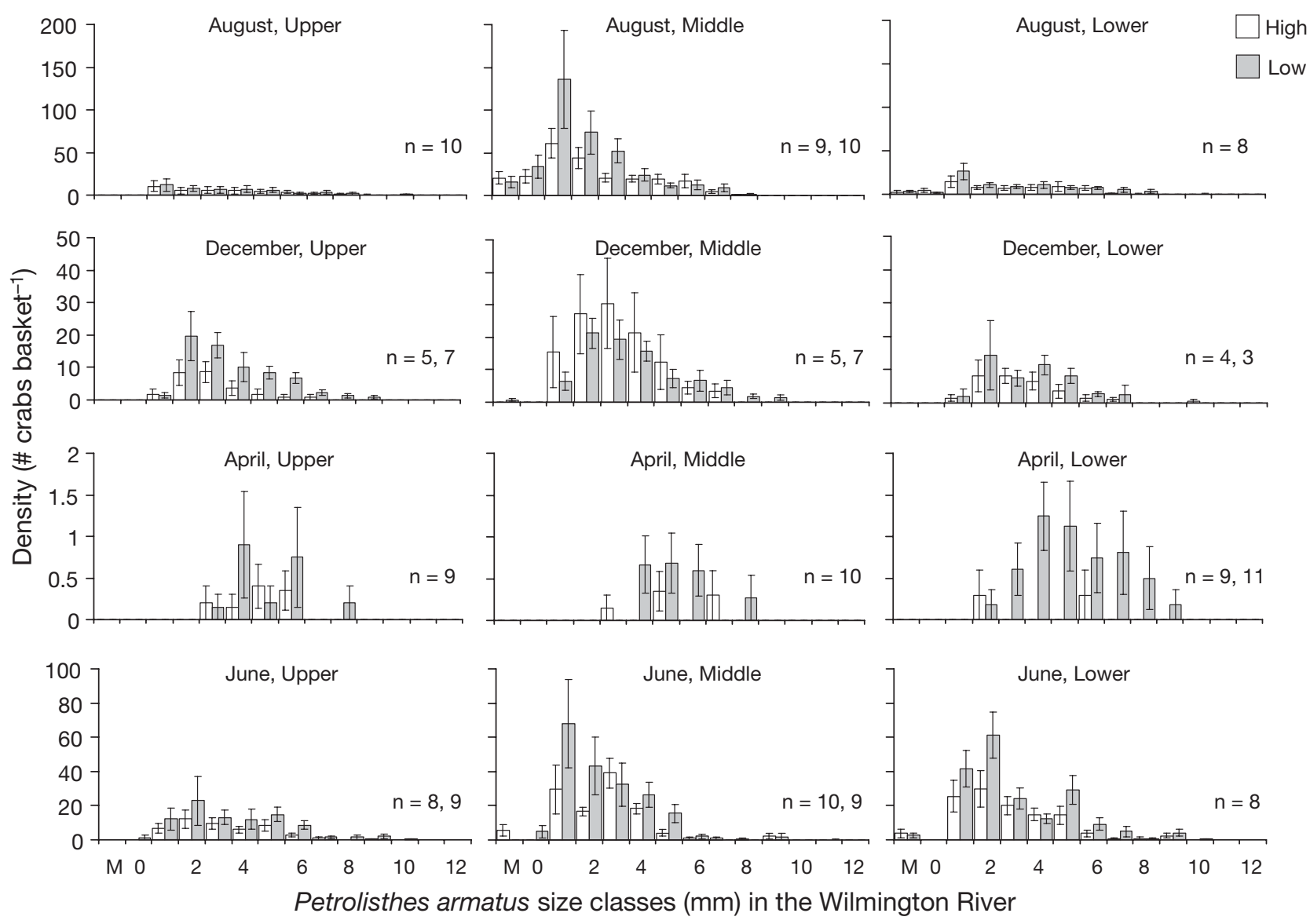

Fig. 4. Petrolisthes armatus. Densities (mean $\pm \mathrm{SE} \mathrm{m}^{-2}$ ) by size class in the Wilmington River. Note different scales for all $y$-axes. Further details as in Fig. 3

Correlations of mud crab density basket ${ }^{-1}$ with Petrolisthes armatus density basket ${ }^{-1}$ across each region, tidal height, and season, indicated several significant positive relationships but no significant negative relationships (Table 4). Of the 24 contrasts in each estuary system, 5 (Wilmington River) or 6 (Duplin River) were significantly positive $(\mathrm{p}<0.050)$, with all but one of these occurring during the warmer periods of the year (June and July, August and September).

\section{DISCUSSION}

Invasive species pose serious threats to native communities (Carlton \& Geller 1993). These invasions have fundamentally changed the community composition of areas such as the San Francisco and the Chesapeake Bays, and they continue to threaten native communities of many coastal marine systems (Ruiz et al. 1999). Successful invasions of marine communities have been studied far less than those in terrestrial and freshwater environments but are of such magnitude that they may lead to profound ecological changes in the world's oceans (Grosholz 2002).

Crabs, in particular, have had wide-ranging impacts on native organisms and communities. Introduced crabs affect the induction of morphological defenses (Trussell \& Nicklin 2002), trait-mediated indirect effects on prey (Trussell et al. 2002), the evolution of defenses (Vermeij et al. 1981), and even the success of bivalve fisheries (Walton et al. 2002).

The exotic crab Petrolisthes armatus has established itself in tremendous densities over broad spatial scales in coastal Georgia, suggesting that it could significantly impact oyster reef communities throughout the South Atlantic Bight. P. armatus was the most abundant crab in oyster reefs at both our northern and more southern sites. At some locations and times, mean densities reached $11200 \mathrm{crabs} \mathrm{m}^{-2}$, which is 37 times greater than the highest density ever documented through trapping studies performed in the crab's historic range (Oliveira \& Masunari 1995). P. armatus persisted throughout the year, colonizing, growing, and reproducing rapidly during the warmer months. The 

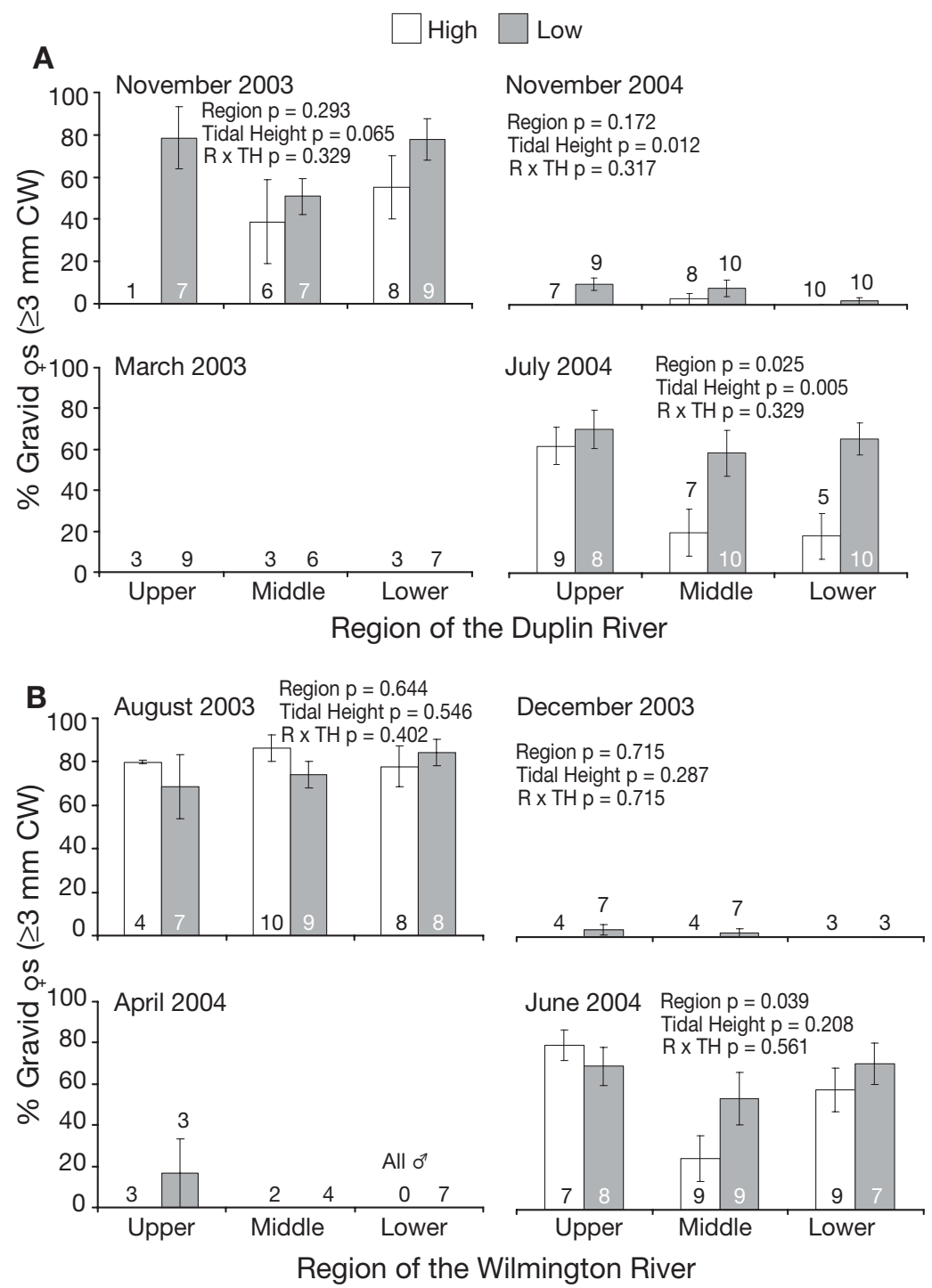

Fig. 5. Petrolisthes armatus. Proportion of mature females ( $\geq 3 \mathrm{~mm} \mathrm{CW}$; mean \pm $\mathrm{SE}$ ) that were gravid in (A) Duplin River and (B) Wilmington River across regions, R, tidal heights, TH (high and low intertidal), and sampling periods. Sampling size was commonly lowered because reproductive, mature females were absent from some baskets. Statistical evaluations not calculated for March and April 2004 because of severely limited sample size. Numbers within or above bars indicate number of replicate baskets sampled. p-values from a 2-way ANOVA following arcsine transformation of data

highest mean densities of $P$. armatus found at any site during monitoring in the warm months exceeded, by $\sim 2$ to 10 times, the highest combined densities of the 2 most common native crabs normally found on Georgian oyster reefs, Panopeus herbstii and Eurypanopeus depressus. High densities of Petrolisthes armatus are not only found on the Georgia coast, densities of thousands $\mathrm{m}^{-2}$ are also reported for South Carolina (South Carolina Department of Natural Resources: www.dnr.sc.gov/marine/sertc/P\%20armatus $\%$ 20SOM.pdf).
In Georgian estuaries, Petrolisthes armatus was found at mean densities of thousands $\mathrm{m}^{-2}$ in warmer portions of the year with localized patches of up to 1036 crabs $0.03 \mathrm{~m}^{-2}$ (= 31390 crabs $\left.\mathrm{m}^{-2}\right)$. During colder months, crab densities declined dramatically: 64 to $95 \%$ in the Duplin River and 89 to $>99 \%$ in the Wilmington River. Distributions of crab size classes indicated that local populations of adult porcelain crabs persisted throughout the winter for all region $\times$ tidal height combinations in both estuaries. These numbers included both males and females of reproductive size and indicate that $P$. armatus has established a viable local population that persists year-round. Observations of larval development in the laboratory have indicated that $P$. armatus reach their final molt before settlement within a relatively short period of time $(\sim 15$ to 17 d, A. L. Hollebone pers. obs.). These 2 factors suggest that warmseason increases in density could result from local reproduction and recruitment, and need not rely on propagule input from more southerly populations in the historic range (e.g. Florida).

\section{Tidal distribution}

Spatial and temporal patterns of density and reproduction could be affected by physiological or biological constraints on the crabs. Work with the porcelain crabs Petrolisthes cinctipes and P. eriomerus in Washington, USA, and British Columbia, Canada, showed that both biotic (competition and predation) and abiotic (thermal tolerance and substrate composition) factors affect their distribution in the intertidal (Jensen \& Armstrong 1991). Both species were susceptible to desiccation, with smaller individuals being at greater risk; and $P$. eriomerus was particularly susceptible to thermal stress during low tides. The higher densities of $P$. armatus in the low intertidal at the sites we monitored, particularly during the warmer months of the year, could be explained by desiccation and heat stress in the high intertidal causing crabs to move to lower elevations. Extreme low tides (the times when we concentrated our sampling) are not sudden events; tides drop increasingly lower for several days prior to the lowest low tide. This could cause crab mortality at high 
Table 2. Petrolisthes armatus. Sex ratios of crabs $>1 \mathrm{~mm} \mathrm{CW}$ analyzed by $\chi^{2}$ tests $\left({ }^{*} 0.025<\mathrm{p}<0.050,{ }^{* *} \mathrm{p}<0.010\right)$ in 3 regions (Upper, Middle, Lower) of river estuaries at 2 tidal heights (High, Low)

\begin{tabular}{|c|c|c|c|c|}
\hline \multirow[t]{2}{*}{ Sampling period } & \multicolumn{2}{|c|}{ Duplin River } & \multicolumn{2}{|c|}{ Wilmington River } \\
\hline & Male:Female & Ratio & Male:Female & Ratio \\
\hline \multicolumn{5}{|l|}{ Aug-Sep 2003} \\
\hline Upper High & $1: 1$ & 1.00 & $53: 51$ & 1.04 \\
\hline Upper Low & $20: 20$ & 1.00 & $60: 66$ & 0.91 \\
\hline Middle High & $25: 11$ & $2.27^{*}$ & $122: 132$ & 0.92 \\
\hline Middle Low & $53: 46$ & 1.15 & $114: 133$ & 0.86 \\
\hline Lower High & $76: 68$ & 1.12 & $88: 112$ & 0.79 \\
\hline Lower Low & $113: 110$ & 1.03 & $115: 112$ & 1.03 \\
\hline \multicolumn{5}{|l|}{ Nov-Dec 2003} \\
\hline Upper High & $20: 24$ & 0.83 & $24: 14$ & 1.71 \\
\hline Upper Low & $98: 93$ & 1.05 & $83: 61$ & 1.36 \\
\hline Middle High & $49: 37$ & 1.32 & $60: 39$ & $1.54^{*}$ \\
\hline Middle Low & $82: 93$ & 0.88 & $97: 104$ & 0.93 \\
\hline Lower High & $98: 78$ & 1.26 & $37: 22$ & 1.68 \\
\hline Lower Low & 106:109 & 0.97 & $28: 32$ & 0.88 \\
\hline \multicolumn{5}{|l|}{ Mar-Apr 2004} \\
\hline Upper High & $9: 5$ & 1.80 & $3: 3$ & 1.00 \\
\hline Upper Low & $30: 21$ & 1.43 & $3: 7$ & 0.43 \\
\hline Middle High & $4: 3$ & 1.33 & $1: 3$ & 0.33 \\
\hline Middle Low & $17: 14$ & 1.21 & $6: 4$ & 1.50 \\
\hline Lower High & $2: 6$ & 0.33 & $2: 0$ & $100 \%$ व \\
\hline Lower Low & $21: 19$ & 1.11 & $14: 15$ & 0.93 \\
\hline \multicolumn{5}{|l|}{ Jun-Jul 2004} \\
\hline Upper High & $33: 45$ & 0.73 & $73: 64$ & 1.14 \\
\hline Upper Low & $49: 51$ & 0.96 & $72: 87$ & 0.83 \\
\hline Middle High & $49: 36$ & 1.36 & $142: 139$ & 1.02 \\
\hline Middle Low & 109:116 & 0.94 & $112: 132$ & 0.85 \\
\hline Lower High & $34: 30$ & 1.13 & 138:111 & 1.24 \\
\hline Lower Low & $135: 186$ & $0.73^{* *}$ & 100:99 & 1.01 \\
\hline
\end{tabular}

tidal heights or the crabs may move down the tidal gradient as the tides progress over time. Despite the potential bias introduced by sampling during the lowest tidal cycles, we still documented densities of up to $\sim 6400$ crabs $\mathrm{m}^{-2}$ in the high intertidal during some periods.

Competition with local crabs appears unlikely to limit tidal height distributions. The abundance of native crabs between tidal heights was not the inverse of Petrolisthes armatus patterns and there were no negative correlations between $P$. armatus and mud crab abundance. $P$. armatus is a filter-feeder while mud crabs are predators. Because mud crabs readily consume $P$. armatus in laboratory assays (Hollebone 2006), the positive correlations for the 2 crabs could result from mud crabs accumulating in locations with high densities of favored prey. Alternatively, both native and non-native crabs may have similar physical needs and thus co-occur at high densities in favorable environments. Regardless of the interactions driving these patterns, the lack of negative correlations between native and invasive crabs suggests that mud crabs are not displacing $P$. armatus into the lower intertidal.

\section{Regional distribution}

Regional distribution of Petrolisthes armatus might be affected by the thermal environment of the estuary, which is strongly influenced by hydrography (Bahr \& Lanier 1981). Typically, temperature does not show a pronounced vertical gradient in the water column in the Lower regions of the estuary but is subject to daily fluctuations (Bahr \& Lanier 1981). During the warmer months of the year, the cooler ocean water temperatures have a moderating effect on the Lower estuary, whereas water temperatures of the marsh creeks and Upper estuary are higher due to the heating of dark sediments during low tides (Bahr \& Lanier 1981). Data collected in 2003 (during a portion of the monitoring program) from the Sapelo Island National Estuarine Research Reserve (SINERR) hydrographic monitoring stations (http://gce-lter.marsci.uga.edu/ lter/data/gce_data.htm) at Sapelo Island, Georgia (Upper site: Flume Dock; Lower site: Marsh Landing) support Bahr \& Lanier's (1981) generalizations. From June to September 2003, the Upper region of the Duplin River estuary was, in general, warmer $\left(\sim 25\right.$ to $\left.32.5^{\circ} \mathrm{C}\right)$ than the Lower region $\left(\sim 25\right.$ to $\left.30^{\circ} \mathrm{C}\right)$. By November and December 2003, water temperatures in the Upper region were similar to $\left(\sim 8\right.$ to $\left.25^{\circ} \mathrm{C}\right)$ or colder than, those in the Lower region $\left(\sim 10\right.$ to $\left.25^{\circ} \mathrm{C}\right)$.

In its native range, Petrolisthes armatus thrives under thermal conditions within the range of spring and autumn temperatures of the South Atlantic Bight (16 to $29^{\circ} \mathrm{C}$ at Farol Island, Paraná, Brazil [Oliveira \& Masunari 1995] and 20.8 to $28.7^{\circ} \mathrm{C}$ at Paranapuã Beach, São Vicente, Brazil [Micheletti-Flores \& Negreiros-Fransozo 1999]). In Brazil the highest densities of P. armatus occurred during the summer when mean surface water temperatures were above $25^{\circ} \mathrm{C}$ (Oliveira \& Masunari 1995). Upper thermal tolerance limits of Petrolisthes spp. are positively correlated with surface water temperatures and with maximal temperatures of microhabitats where crabs occur (Stillman \& Somero 2000). In laboratory studies $P$. armatus has an upper thermal tolerance of $40.5^{\circ} \mathrm{C}$ (Stillman \& Somero 2000). Therefore, $P$. armatus can probably survive increased temperatures as a result of low tide exposure as long as microhabitats remain below this upper thermal limit.

Water temperatures during the winter in Georgia are well below the minimal $16^{\circ} \mathrm{C}$ temperature recorded in the crab's native range (Oliveira \& Masunari 1995). 


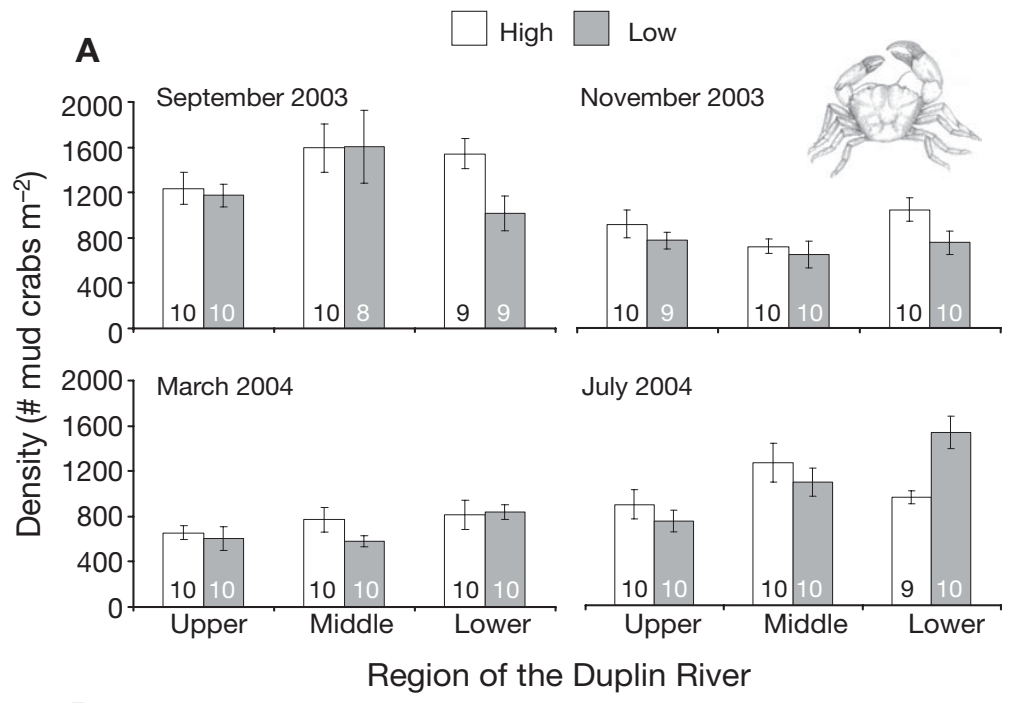

\section{B}

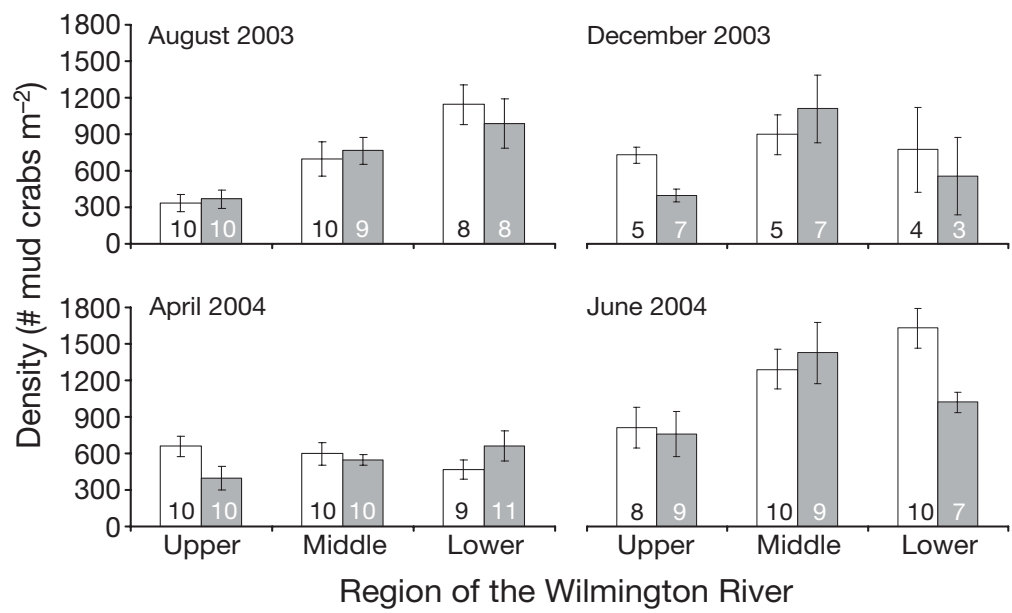

Fig. 6. Panopeus herbstii and Eurypanopeus depressus (native mud crabs). Densities (mean $\pm \mathrm{SE}$, scaled to $1 \mathrm{~m}^{2}$ ) in (A) Duplin River and (B) Wilmington River across regions, tidal heights, and sampling period. Numbers within bars indicate number of replicate baskets sampled. For statistical analyses see Table 3
Seasonally low temperatures in Georgia may exceed the lower thermal limit of crabs in many habitats, causing the large decrease in densities we observed during colder months. This effect was documented for blue crabs Callinectes sapidus at Sapelo Island, Georgia, when water temperatures fell below $15^{\circ} \mathrm{C}$ (Fitz \& Wiegert 1991). Seasonality also affects the strata habitation of the mud crabs Panopeus herbstii and Eurypanopeus depressus in oyster reefs of North Carolina (Meyer 1994). During warmer months, mud crabs more frequently inhabited the cluster stratum of the oyster reefs, whereas in the colder months they inhabited the subsurface stratum.

Alterations in salinity seem less likely to determine the distribution or abundance of Petrolisthes armatus at our sites because the crab lives at salinities of 6.7 to $31.5 \%$ in its native range (Oliveira \& Masunari 1995). This salinity range brackets salinities at our monitoring sites. Salinities in the Duplin River ranged from 13 to $30 \%$ (see http://gcelter.marsci.uga.edu/lter/data/gce_data.htm), whereas those in the portions of the Wilmington River we monitored ranged from 15 to $31 \%$ (Coastal Georgia Adopt-A-Wetland unpubl. data) during the time periods we monitored.

\section{Reproduction}

The dramatic seasonal change in densities (e.g. from $\sim 60$ crabs $\mathrm{m}^{-2}$ in the middle region of the Wilmington River in April 2004 to 6000 crabs $\mathrm{m}^{-2}$ in June 2004), the considerable den-

Table 3. Panopeus herbstii and Eurypanopeus depressus. 3-way ANOVA of density with estuary, time period, and tidal height as fixed factors and region nested within estuary

\begin{tabular}{|lrrrrrr}
\hline Source & df & Seq SS & Adj SS & Adj MS & $F$ & $\mathrm{p}$ \\
\hline Estuary & 1 & 1890.3600 & 1798.9700 & 1798.9700 & 35.55 & $\leq 0.001$ \\
Time period & 3 & 4301.8600 & 4442.7700 & 1480.9200 & 29.26 & $\leq 0.001$ \\
Tidal height & 1 & 257.4800 & 242.9300 & 242.9300 & 4.80 & 0.029 \\
Region (Estuary) & 4 & 2504.8600 & 2017.2800 & 504.3200 & 9.97 & $\leq 0.001$ \\
Estuary $\times$ Time & 3 & 2038.0400 & 1773.4900 & 591.1600 & 11.68 & $\leq 0.001$ \\
Estuary $\times$ Tidal height & 1 & 0.2800 & 0.0200 & 0.0200 & 0.00 & 0.985 \\
Time period $\times$ Tidal height & 3 & 37.6900 & 60.3800 & 20.1300 & 0.40 & 0.755 \\
Time period $\times$ Region (Estuary) & 12 & 2007.2500 & 1985.4600 & 165.4500 & 3.27 & $\leq 0.001$ \\
Tidal height $\times$ Region (Estuary) & 4 & 231.8200 & 264.4000 & 66.1000 & 1.31 & 0.267 \\
Estuary $\times$ Time period $\times$ Tidal height & 3 & 131.2900 & 135.6600 & 45.2200 & 0.89 & 0.445 \\
Time period $\times$ Tidal height $\times$ Region (Estuary) & 12 & 1081.8100 & 1081.8100 & 90.1500 & 1.78 & 0.049 \\
Error & 385 & 19482.7100 & 19482.7100 & 50.6000 & & \\
Total & 432 & 33965.4200 & & & & \\
\end{tabular}


Table 4. Panopeus herbstii, Eurypanopeus depressus, and Petrolisthes armatus. Correlations (Fisher's $r$ to $z$ ) of densities of native mud crabs versus exotic porcelain crabs in Duplin River estuary and Wilmington River estuary. Bold p-values indicate significant correlations $(p<0.050)$. Further details as in Table 2

\begin{tabular}{|c|c|c|c|c|c|c|c|c|}
\hline \multirow{2}{*}{ Sampling period } & \multirow[b]{2}{*}{$\mathrm{n}$} & \multicolumn{3}{|c|}{ Duplin River } & \multirow[b]{2}{*}{$\mathrm{n}$} & \multicolumn{2}{|c|}{ Wilmington River } & \multirow[b]{2}{*}{$\mathrm{p}$} \\
\hline & & Correlation & $z$ & $\mathrm{p}$ & & Correlation & $z$ & \\
\hline \multicolumn{9}{|l|}{ Aug-Sep 2003} \\
\hline Upper High & 10 & 0.079 & 0.210 & 0.834 & 10 & 0.780 & 2.769 & 0.006 \\
\hline Upper Low & 10 & 0.269 & 0.731 & 0.465 & 10 & 0.791 & 2.842 & 0.005 \\
\hline Middle High & 10 & 0.601 & 1.838 & 0.066 & 10 & -0.100 & -0.267 & 0.790 \\
\hline Middle Low & 8 & 0.780 & 2.339 & 0.019 & 9 & 0.164 & 0.406 & 0.685 \\
\hline Lower High & 9 & 0.837 & 2.966 & 0.003 & 8 & 0.333 & 0.774 & 0.439 \\
\hline Lower Low & 9 & 0.294 & 0.742 & 0.458 & 8 & 0.712 & 1.992 & 0.046 \\
\hline \multicolumn{9}{|l|}{ Nov-Dec 2003} \\
\hline Upper High & 10 & 0.208 & 0.557 & 0.577 & 5 & 0.384 & 0.572 & 0.568 \\
\hline Upper Low & 9 & -0.473 & -1.260 & 0.208 & 7 & 0.276 & 0.567 & 0.571 \\
\hline Middle High & 10 & 0.116 & 0.309 & 0.758 & 5 & 0.433 & 0.655 & 0.513 \\
\hline Middle Low & 10 & 0.366 & 1.015 & 0.310 & 7 & 0.157 & 0.316 & 0.752 \\
\hline Lower High & 10 & -0.247 & -0.667 & 0.505 & 4 & 0.638 & 0.754 & 0.451 \\
\hline Lower Low & 10 & 0.760 & 2.636 & 0.008 & 3 & 0.494 & 0.000 & $>0.999$ \\
\hline \multicolumn{9}{|l|}{ Mar-Apr 2004} \\
\hline Upper High & 10 & -0.464 & -1.330 & 0.184 & 10 & -0.423 & -1.193 & 0.233 \\
\hline Upper Low & 10 & 0.306 & 0.836 & 0.403 & 10 & 0.273 & 0.742 & 0.458 \\
\hline Middle High & 10 & -0.574 & -1.728 & 0.084 & 10 & -0.095 & -0.253 & 0.800 \\
\hline Middle Low & 10 & -0.136 & -0.363 & 0.716 & 10 & 0.467 & 1.340 & 0.180 \\
\hline Lower High & 10 & -0.353 & -0.975 & 0.329 & 9 & 0.342 & 0.872 & 0.383 \\
\hline Lower Low & 10 & 0.057 & 0.150 & 0.880 & 11 & -0.058 & -0.164 & 0.870 \\
\hline \multicolumn{9}{|l|}{ Jun-Jul 2004} \\
\hline Upper High & 10 & 0.736 & 2.492 & 0.013 & 8 & 0.717 & 2.016 & 0.044 \\
\hline Upper Low & 10 & 0.212 & 0.569 & 0.569 & 9 & 0.355 & 0.910 & 0.363 \\
\hline Middle High & 10 & 0.919 & 4.187 & $<0.001$ & 10 & 0.244 & 0.659 & 0.510 \\
\hline Middle Low & 10 & 0.157 & 0.419 & 0.675 & 9 & 0.741 & 2.335 & 0.020 \\
\hline Lower High & 9 & 0.470 & 1.251 & 0.211 & 10 & 0.302 & 0.826 & 0.409 \\
\hline Lower Low & 10 & 0.826 & 3.111 & 0.002 & 7 & -0.109 & -0.219 & 0.827 \\
\hline
\end{tabular}

sities of newly recruited crabs in the warmer months, the ability of females to reproduce at sizes as small as $3 \mathrm{~mm} \mathrm{CW}$, the high percentage of egg-bearing females (often 50 to $80 \%$ ), and the high densities of Petrolisthes armatus zooea we noted in plankton tows during the summers of 2003 and 2005 (A. L. Hollebone and W. E. Morrison pers. obs.) all attest to the remarkable ability of the crab to rapidly increase from 10s or 100s of crabs $\mathrm{m}^{-2}$ in the winter to $1000 \mathrm{~s}$ of crabs $\mathrm{m}^{-2}$ in the summer.

The sex ratio within the native range of Petrolisthes armatus at Farol Island, Brazil is about 1.05 males for each female over an entire year (Oliveira \& Masunari 1995). Our data are consistent with this ratio in that across all time periods, regions, and tidal heights, $P$. armatus in Georgia maintained a male:female ratio of about $1: 1$.

At the Duplin River sites, 20 to $85 \%$ of adult female crabs were ovigerous during the spring and summer; for the Wilmington River sites, 25 to $90 \%$ of adult females were ovigerous. At Farol Island, Brazil, Oliveira \& Masunari (1995) found that $\sim 48 \%$ of all females $\geq 4 \mathrm{~mm} \mathrm{CW}$ (or $\sim 34 \%$ of all females $\geq 3 \mathrm{~mm} \mathrm{CW}$ ) were gravid (data combined for all seasons). This figure falls within the range seen in both estuaries we studied, as well as an overall proportion calculated for all females $\geq 3 \mathrm{~mm} \mathrm{CW}$ at all locations throughout the entire year (Duplin River: 30\%; Wilmington River: $48 \%$ ). Thus, invasion of a more temperate habitat has not constrained reproduction by Petrolisthes armatus. Additionally, Oliveira \& Masunari (1995) documented that females in the historic range matured at 4 to $4.9 \mathrm{~mm} \mathrm{CW}$, whereas we found mature females at 3 to $3.9 \mathrm{~mm}$ CW. Crabs in the new range become sexually mature at a smaller size (potentially increasing the number of broods year ${ }^{-1}$ or breeding lifetime ${ }^{-1}$ ), maximal adult densities are commonly 10 to 37 times higher than those seen in Brazil, but the percentage of females that are gravid between new and old range does not differ. Given these contrasts, population fecundity in the invaded range should exceed that in the historic range by at least 1 order of magnitude. It appears that $P$. armatus is more than capable of sustaining its populations locally without relying on seasonal inputs of propagules from more tropical regions. 


\section{Biological factors}

Introduced species often have large impacts on native species via predation and competition (e.g. Nichols et al. 1990, Lodge et al. 1994, MacIsaac 1996), and pre-existing species may repel invasions via the same interactions (e.g. Stachowicz et al. 1999, Parker \& Hay 2005, Parker et al. 2006). We did not experimentally test the impacts of competition and predation on community structure, but correlatively addressed this possibility by evaluating how crab density for both native mud crabs and exotic porcelain crabs covaried over space and time. We saw significant positive relationships in $23 \%$ of the 48 possible correlations of mud and porcelain crabs in both estuaries across all region-tidal height combinations and seasons. Significant negative relationships never occurred. Positive correlations occurred during the warmer months (August and September 2003, June and July 2004) when the densities of Petrolisthes armatus were increasing dramatically and densities of mud crabs were at their peak. Thus, crabs tended to peak at similar times and places. We found no negative correlations that one might expect if the invader were having strong negative effects on native crabs; however, correlations alone do not rigorously address cause-effect relationships. Hollebone (2006) showed that mud crabs readily consume $P$. armatus in the laboratory, suggesting that the positive correlations could occur because mud crabs move to areas of high $P$. armatus densities in order to feed.

\section{Summary}

Despite densities reaching into 1000 s of crabs $\mathrm{m}^{-2}$, the biology and ecological impacts of Petrolisthes armatus on native oyster reef communities is relatively unknown. Unlike invasive predatory crabs that change the activities of native species (Trussell \& Nicklin 2002) and 'reorganize' native assemblages (Lohrer \& Whitlach 2002), the invasion of $P$. armatus has not produced a dramatic or visually obvious change in the oyster reefs of Georgia. However, the invasion may be too recent, or its effects too subtle, to be visually obvious. Short-term, small-scale studies indicate that the crab may suppress oyster growth, microalgal biomass, and juvenile mud crab densities, while enhancing bivalve recruitment (oysters, mussels, and clams), macroalgal growth, and potentially oyster drill survivorship (Hollebone 2006). The combined, longer-term impacts of these effects are unknown, but the densities, high metabolic rates, and filter feeding activity of the crabs suggest that their feeding could move substantial quantities of water column production to the benthos, thus altering biogeochemical processes. Because local fishes and crabs readily consume $P$. armatus, its presence could also be altering native food-webs (Hollebone 2006). Given that oysters are long-lived and that much of their hard structure persists for years after their death, effects of $P$. armatus on this foundation species could take years to become obvious.

Acknowledgements. We thank D.L. Smee, A. Wilson, B. Vallaster, S. VanParreren, and P. Winnubst for field assistance, D. Hurley and the Sapelo Island NERR staff for their consultation and logistical support, with a special thank-you to K. Hollebone for the artwork. We thank J.T. Carlton, A. Cohen, J. Lawrence, M. Miller, T. Snell, J.T. Streelman, M. Weissburg, and an anonymous reviewer for comments that improved the manuscript. Financial support was provided by a NERRS Graduate Research Fellowship (NA03NOS4200063) and an EPA STAR Graduate Fellowship (U-915531-01-0) to A.L.H. with additional funding from the Georgia Institute of Technology and the Harry and Linda Teasley Endowment. This study was part of a PhD dissertation in the School of Biology at the Georgia Institute of Technology.

\section{LITERATURE CITED}

Bahr LM, Lanier WP (1981) The ecology of intertidal oyster reefs of the South Atlantic coast: a community profile. (FWS/OBS-81/15) United States Fish and Wildlife Service, Office of Biological Sciences, Washington, DC

Carlton JT, Geller JB (1993) Ecological roulette: the global transport of nonindigenous marine organisms. Science 261:78-82

Chalmers AG (1997) The ecology of the Sapelo Island National Estuarine Research Reserve. NOAA Office of Resource Management, Sanctuaries and Reserves Division and Georgia Department of Natural Resources, Parks and Historic Sites Division

Coen LD, Heck KL (1983) Notes on the biology of some seagrass-dwelling crustaceans (Stomatopoda and Decapoda) from Caribbean Panama. Proc Biol Soc Wash 96:202-224

Cohen AN, Carlton JT (1998) Accelerating invasion rate in a highly invaded estuary. Science 279:555-557

Fitz HC, Wiegert RG (1991) Utilization of the intertidal zone of a saltmarsh by the blue crab Callinectes sapidus-density, return frequency, and feeding habits. Mar Ecol Prog Ser 76:249-260

Grosholz ED (2002) Ecological and evolutionary consequences of coastal invasions. Trends Ecol Evol 17:22-27

Hollebone AL (2006) An invasive crab in the South Atlantic Bight: friend or foe? PhD dissertation, Georgia Institute of Technology, Atlanta

Jensen GC, Armstrong DA (1991) Intertidal zonation among congeners: factors regulating distribution of porcelain crabs Petrolisthes spp. (Anomura: Porcellanidae). Mar Ecol Prog Ser 73:47-60

Lenihan HS, Peterson CH (1998) How habitat degradation through fishery disturbance enhances impacts of hypoxia on oyster reefs. Ecol Appl 8:128-140

Lodge DM (1993) Biological invasions: lessons for ecology. Trends Ecol Evol 8:133-137

Lodge DM, Kershner MW, Aloi JE, Covich AP (1994) Effects of omnivorous crayfish (Oronectes rusticus) on a freshwater littoral food web. Ecology 75:1265-1281 
Lohrer AM, Whitlach RB (2002) Interactions among aliens: apparent replacement of one exotic species by another. Ecology 83:719-732

MacIsaac HJ (1996) Potential abiotic and biotic impacts of zebra mussels on the inland waters of North America. Am Zool 36:287-299

Meyer DL (1994) Habitat partitioning between the xanthid crabs Panopeus herbstii and Eurypanopeus depressus on intertidal oyster reefs (Crassostrea vriginica) in southeastern North Carolina. Estuaries 17:674-679

Micheletti-Flores CV, Negreiros-Fransozo ML (1999) Porcellanid crabs (Crustacea, Decapoda) inhabiting sand reefs built by Phragmatopoma lapidosa (Polychaeta, Sabellariidae) at Paranapua Beach, Sao Vicente, SP, Brazil. Rev Bras Biol 59:63-73

Mooney HA, Drake JA (1986) Ecology of biological invasions of North America and Hawaii, Springer-Verlag, New York

Nichols FH, Thompson JK, Schemel LE (1990) Remarkable invasion of San Francisco Bay (California, USA) by the Asian clam Potamocorbula amurensis. II. Displacement of a former community. Mar Ecol Prog Ser 66:95-101

Oliveira E, Masunari S (1995) Estrutura populacional de Petrolisthes armatus (Gibbes) (Decapoda, Anomura, Porcellanidae) da Ilha do Farol, Matinhos, Parana, Brasil. Rev Bras Zool 12:355-371

Parker JD, Hay ME (2005) Biotic resistance to plant invasions? Native herbivores prefer non-native plants. Ecol Lett 8: 959-967

Parker JD, Burkepile DE, Hay ME (2006) Opposing effects of native and exotic herbivores on plant invasions. Science 311:1459-1461

Ragotzkie RA, Bryson RA (1955) Hydrography of the Duplin River, Sapelo Island, Georgia. Bull Mar Sci Gulf Caribb 5: 297-314

Ruiz GM, Carlton JT, Grosholz ED, Hines AH (1997) Global invasions of marine and estuarine habitats by non-indige-

Editorial responsibility: John Lawrence (Contributing Editor), Tampa, Florida, USA nous species: mechanisms, extent, and consequences. Am Zool 37:621-632

Ruiz GM, Fofonoff P, Hines AH, Grosholz ED (1999) Nonindigenous species as stressors in estuarine and marine communities: assessing invasion impacts and interactions. Limnol Oceanogr 44:950-972

Sheridan PF (1992) Comparative habitat utilization by estuarine macrofauna within the mangrove ecosystem of Rookery Bay, Florida. Bull Mar Sci 50:21-39

Simberloff D, Schmitz DC, Brown TC (1997) Strangers in paradise: impact and management of nonindigenous species in Florida. Island Press, Washington, DC

Stachowicz JJ, Whitlach RB, Osman RW (1999) Species diversity and invasion resistance in a marine ecosystem. Science 286:1577-1579

Stillman JH, Somero GN (2000) A comparative analysis of the upper thermal tolerance limits of Eastern Pacific porcelain crabs, Genus Petrolisthes: influences of latitude, vertical zonation, acclimation, and phylogeny. Physiol Biochem Zool 73:200-208

Trussell GC, Nicklin MO (2002) Cue sensitivity, inducible defense, and trade-offs in a marine snail. Ecology 83: 1635-1647

Trussell GC, Ewanchuk PJ, Bertness MD (2002) Field evidence of trait-mediated indirect interactions in a rocky intertidal food web. Ecol Lett 5:241-245

Vermeij GJ, Schindel DE, Zipser E (1981) Predation through geological time-evidence from gastropod shell repair. Science 214:1024-1026

Walton WC, MacKinnon C, Rodriguez LF, Proctor C, Ruiz GA (2002) Effect of an invasive crab upon a marine fishery: green crab, Carcinus maenas, predation upon a venerid clam, Katelysia scalarina, in Tasmania (Australia). J Exp Mar Biol Ecol 272:171-189

Zar JH (1999) Biostatistical analysis, 4th edn. Prentice Hall, Upper Saddle River, NJ

Submitted: December 13, 2005; Accepted: July 3, 2006

Proofs received from author(s): March 27, 2007 